\title{
What drives the capital structure? The case of non-life insurance companies in Serbia
}

\author{
Article history: \\ Received: 16 January 2021 \\ Sent for revision: 20 February 2021 \\ Received in revised form: 28 February 2021 \\ Accepted: 12 March 2021 \\ Available online: 30 April 2021
}

\begin{abstract}
This paper studies the factors behind the capital structure of insurance companies. We used financial reports of non-life and composite insurance companies in Serbia between 2006 and 2019. In particular, we apply a panel-data approach to examine the relationship between leverage, defined as the ratio of technical reserves to capital and various firm-level characteristics. The coefficients estimated using the individual fixed-effects model indicate a significant and negative influence of profitability, growth and liquidity measures on leverage and a significant and positive influence of company size. The results indicate that the tradeoff theory and the pecking order theory are relevant in explaining the non-life insurer capital structure in Serbia.
\end{abstract}

Keywords: non-life insurance, capital structure, leverage, tradeoff theory, pecking order theory

\section{Šta određuje strukturu kapitala? Slučaj kompanija za neživotno osiguranje u Srbiji}

Apstrakt: Rad se bavi faktorima koji utiču na strukturu kapitala kompanija neživotnog osiguranja. Korišćeni su finansijski izveštaji neživotnih $i$ kompozitnih osiguravača koji su poslovali u Srbiji u periodu od 2006. do 2019. Primenjen je pristup panel podataka kako bi se ispitala veza između finansijske poluge, koja je definisana kao količnik tehničkih rezervi $i$ kapitala, i raznih specifičnih osobina

\footnotetext{
1 University of Belgrade, Faculty of Economics, milos.bozovic@ekof.bg.ac.rs

2 University of Belgrade, Faculty of Economics
} 
pojedinačnih kompanija. Ocene koeficijenata dobijene korišćenjem modela individualnih fiksnih efekata ukazuju na postojanje značajnog negativnog uticaja mera profitabilnosti, stope rasta i likvidnosti na koeficijent finansijske poluge, i značajan pozitivan uticaj veličine kompanije. Ovi rezultati ukazuju da su teorija kompromisa i teorija hijerarhijskog poretka relevantne za objašnjavanje strukture kapitala neživotnih osiguravača u Srbiji.

Ključne reči: neživotno osiguranje, struktura kapitala, finansijska poluga, teorija kompromisa, teorija hijerarhijskog poretka

\section{Introduction}

The funding structure of financial institutions gained importance after the Global Financial Crisis. A financial institution's resistance to balance sheet shocks depends on its capital adequacy. For the insurance company, capital serves as a cushion that protects policyholders and promotes the stability and efficiency of the entire financial system. Insurer's capital is the ultimate absorber of risk. Since the primary function of insurance is to protect against risk, appropriate regulations prescribe the minimum level of capital to ensure solvency, wherein the actual capital must be at least equal to the solvency capital requirement. However, the solvency ratio values show that insurers in practice hold higher capital levels than the regulatory required. For example, the average solvency ratio of insurers in the European Union, calculated based on the Solvency II regulatory framework, reached almost $250 \%$ at the end of 2019 , despite the unfavorable macroeconomic conditions (EIOPA, 2020).

The higher the insurer's equity, the higher the probability that insurance liabilities will be duly settled in full. However, in an imperfect capital market, the cost of capital is also higher (Laeven \& Perotti, 2010). When deciding on the optimal level of capital, insurers face a tradeoff between satisfying the interests of policyholders and supervisors, on the one hand, and investors' interests, on the other.

This paper investigates the company-level drivers of the capital structure of non-life insurers in Serbia. We examine the classical theories of capital structure by identifying and measuring the influence of its key determinants. We also study whether the variables that explain the capital structure in developed financial markets are relevant for Serbian insurance market too. More specifically, we use financial reports of non-life and composite insurance companies in Serbia between 2006 and 2019 and apply a panel-data approach to examine the determinants of leverage. As a proxy for leverage, we use the ratio of technical reserves to capital. We then regress this ratio on the 26 
company's age, size, growth, the concentration of business lines, profitability, liquidity and risk. The fixed-effects model gives two striking results. On the one hand, we find a significant and positive influence of company size and a significant and negative influence of growth, as in the tradeoff theory. On the other hand, there is a significant and negative influence of profitability and liquidity measures on leverage, according to the pecking order theory.

As far as we know, this is one of the first studies investigating the financing determinants for insurance companies in Serbia. The paper also provides a comprehensive overview of previous studies on this topic regarding the insurance sector. Throughout the overview, we point out a relevant research gap: most of the literature is based on studies conducted for other industries, not comparable with insurance. We also contribute by introducing the ratio of technical reserves to capital as the leverage measure. This ratio is a more natural measure of an insurer's capital structure, in contrast to some general leverage ratios commonly used in the literature (e.g., the surplus to assets ratio, debt to equity, or total debt to total assets).

The remainder of the paper is structured as follows. In section 2, we provide a brief review of theoretical and empirical studies relevant to this research. Section 3 explains data sources and methodology. Results and discussion are given in Section 4, while Section 5 concludes.

\section{Theoretical background and empirical evidence}

\subsection{Theories of capital structure}

Determinants of the firm's capital structure represent one of the fundamental issues in corporate finance. Attempts to explain the proportions of debt and equity in financing corporations' assets have yielded several capital structure theories. Although there is no universal theory, several conditional theories can be distinguished by their relative focus on the factors that could significantly impact the capital structure. These factors include both firm-specific and external features - institutional, industry-related and macroeconomic (Hermanns, 2006). These aspects could be relevant for some firms, and their relative importance depends on circumstances (Myers, 2003). Traditionally, the central part of the debate concerning capital structure choices revolves around tradeoff and the pecking order theories.

Modigliani and Miller (1958) laid the foundations of capital structure theory with their irrelevance proposition. According to this proposition, in an efficient market without taxes, bankruptcy costs and asymmetric information, the firm's value 
should not depend on its capital structure. Therefore, in a perfect market, the firm's financing means are irrelevant. However, once we relax the unrealistic assumptions on which this theory hinges, the choice of the capital structure becomes indispensable.

The tradeoff theory arose from criticism of Modigliani and Miller theorem by including the income tax to the original irrelevance proposition. This theory holds that firms strive for optimal debt by balancing between the tax shield and bankruptcy costs (Kraus \& Litzenberger, 1973). A firm that follows the tradeoff theory should set an objective debt-equity ratio and progressively shift towards it (Myers, 1984). Frank \& Goyal (2005) made a distinction between the static tradeoff theory (according to which firms essentially undergo a cost-benefit analysis of issuing debt) and the dynamic tradeoff theory (claiming that leverage exhibits target adjustments).

The pecking order theory conjectures that firms' financing decisions are conditioned by differences in information between insiders (managers) and outside investors (Myers \& Majluf, 1984). Since outsiders have less information about the firm's prospects, debt and equity may be mispriced. Thus, the theory claims that the firm will choose debt over equity when inflows are insufficient to finance capital expenditures (Myers, 2001). Hence, the pecking order theory's key prediction is the strict ordering of financing, starting with retained earnings, succeeded by debt, and raising additional equity as the ultimate financing means. Compared to the tradeoff theory, the pecking order theory does not assume the optimal firms' capital structure as a competing theory.

\subsection{Empirical evidence}

Several firm-specific determinants of the capital structure were identified within empirical studies conducted in different markets. However, these studies are mainly inclined toward non-financial firms in developed economies. The applicability of their conclusions to insurance companies and less developed financial systems has gained importance recently. Although many drivers of the capital structure decisions were identified for the insurance industry, only a few happen to be robust across different studies. These factors include profitability, age, size, diversification, growth opportunities, liquidity and business risk.

Depending on the theory, the relationship between leverage and profitability may go in both directions. On the one hand, the tradeoff theory suggests a positive link. Namely, as profitability increases, the probability of financial distress and expected bankruptcy costs decrease. Since the interest payments are typically tax-deductible, firms increase their leverage to exploit tax shields. On the other hand, the pecking order theory states that leverage and profitability 28 
are negatively related, as firms utilize the retained earnings first and then opt for debt. Since profitable firms earn more, they presumably rely less on debt than firms with lower earnings.

The evidence on the leverage-profitability nexus is also conflicting. Using data from 1993 to 2004, Shim (2010) demonstrated that leverage and profitability for U.S. non-life insurers have a negative relationship. The pecking order theory is also confirmed in an empirical study of the capital structure of 350 Dutch insurers during the period 1995-2005 conducted by de Haan \& Kakes (2010). Ahmed et al. (2010) analyzed the Pakistani life insurance sector and found a negative relationship between leverage and profitability. The same relationship was shown for Turkish non-life insurance companies between 2006 and 2013 in the study by Öner Kaya (2015). Using a panel of Ethiopian insurance companies, Kinde (2013) found a mixed profitability impact depending on a proxy used for insurers' leverage. There is a negative relation of profitability with the long-term debt ratio and a positive relation with the total debt ratio.

The measure used to capture firm profitability is also essential. An empirical study by Ahmed \& Bhuyan (2020) on Australian service sector companies suggests that leverage is positively related to operating margin and return on equity (ROE) but negatively related to return on assets (ROA). Furthermore, examining determinants of leverage ratio of French, German and British firms, Antoniou et al. (2002) showed that the direction of influence of profitability differs across countries. On the other hand, using panel data set for U.S. nonlife-insurers, Harrington \& Niehaus (2002) provided evidence that leverage ratios for mutual insurers are more sensitive to profitability changes than stock insurers' leverage ratios.

The firm's age as a proxy of its reputation has been used as an explanatory variable in many empirical capital structure models, especially in developing insurance markets. Myers (2001) states that as a firm survives for a long time, it progressively builds its reputation and increases its borrowing capacity. Moreover, with time more information regarding the company's future performance becomes available, which reduces informational asymmetries. Hence, age is positively related to leverage, as confirmed by several studies in the insurance sector. For example, a study conducted by Sherif \& Elsayed (2013) showed that the age of the Egyptian insurance companies is positively related to their leverage. Guruswamy \& Marew (2016) also estimated a positive and significant impact of age on leverage for the Ethiopian insurance companies between 2005 and 2014.

Altuntas, Berry-Stölzle \& Wende (2015) used data from life and non-life insurers across 28 different countries between 2001 and 2008. They found a heterogeneous capital structure across countries. Based on a static variance 
decomposition analysis, they concluded that the firm-specific factors explain less than 27 percent of insurer leverage variation, with the firm size having the highest explanatory power among them. Large insurers tend to be more diversified than the smaller ones. Diversification reduces variations in their earnings and allows them to increase their leverage. According to the law of large numbers, the greater the insurance portfolio, the smaller the degree of variation in the annual aggregate claim amount, ceteris paribus. Therefore, larger insurers can operate with a relatively smaller capital buffer and higher financial leverage (Cummins \& Nini, 2002). The positive impact of firm size on its leverage ratio is in agreement with the tradeoff theory. The pecking-order rationale is the opposite: larger firms suffer less from information asymmetry problems and better access to capital markets, which is why they would deploy more equity and less debt. Most authors encountered a positive relationship between size and leverage in the insurance sector (e.g., Harrington \& Niehaus, 2002; Shim, 2010; de Haan \& Kakes, 2010; Tornyeva, 2013).

Insurance companies also tend to diversify risk over business lines or locations. Several prior studies included the Herfindahl-Hirschman index $(\mathrm{HHI})$ for product mix or geographic spread to analyze insurers' capital structure. As the $\mathrm{HHI}$ increases, the underwriting portfolio becomes more concentrated (i.e., less diversified). Since the tradeoff theory argues that more diversified insurers require less capital to operate, a higher level of $\mathrm{HHI}$ intends to decrease the degree of leverage. A negative relation between the $\mathrm{HHI}$ and liabilities-toassets ratio is confirmed by Cheng \& Weiss (2012) for a sample of U.S. nonlife insurers.

According to the static tradeoff theory, higher growth is typically accompanied by financial distress. Therefore, growing companies should be predominantly equity-financed. However, the pecking-order hypothesis is that growing firms turn to external sources once they get close to exhausting the internally generated funds. The growth of the insurer's portfolio, either through an increase in the number of existing contracts and premiums or the development of new products and expansion to other markets, implies an increase in technical reserves to back liabilities to new policyholders. Thus, if the equity levels remain unchanged, financial leverage increases and the net effect of growth on leverage is undetermined. Cheng \& Weiss (2012) confirmed the positive and statistically significant impact of growth opportunities on the leverage ratio, defined as the net premiums written to surplus ratio. Fier, McCullough \& Carson (2013) found a similar result for affiliated U.S. insurers. Shim (2010) proved the opposite for the same insurance market: fast-growing insurers tend to hold more capital due to more outstanding reserve deficiencies and regulatory pressures. 
Traditional theories do not have a single view on the nature of the influence of a firm's liquidity on its capital structure. Companies with higher liquidity might sustain more debt since they are generally efficient in meeting their short-term liabilities. Their debt levels can be sustained because a high liquidity ratio signals creditors that the company is promptly settling its liabilities and that the default risk is low. Harris \& Raviv (1990) also show that the more liquid the assets, the higher the expected liquidation value. Thus, the tradeoff theory predicts that the relationship between the firm's liquidity and leverage is positive.

In contrast, the pecking order theory suggests that more liquid firms will borrow less, as they use liquid assets before they issue new debt. In this regard, Antoniou et al. (2002) argue that firms with higher liquidity do not require to raise external loan capital. Liquidity is essential for non-life insurers - a predominantly short-term nature of their funds requires more liquid shortmaturity instruments in their investment portfolios than life insurers. While Kinde (2013) has confirmed the positive relationship between insurers' liquidity and leverage, Ahmed et al. (2010), Najjar \& Petrov (2011) as well as Takele \& Beshir (2017) proved that this relation is negative.

Previous research on the relationship between an insurer's business risk and its capital structure has yielded two opposing hypotheses. On the one hand, the finite risk paradigm assumes that insurers choose the level of capital and business risk to achieve the target solvency ratio and limit bankruptcy costs, to which risk-based regulation also contributes. Hence, it is logical that higher business risk requires higher capital, i.e., lower financial leverage. This relationship is even more significant in non-life insurance, where some business lines are characterized by exposure to catastrophic risks and high volatility of claims. The excessive risk paradigm argues that insurers do not put bounds on total risk, so the link between business risk and financial leverage may be positive. A key argument of this view is the existence of guarantee funds that provide incentives for insurers to increase the risk as capital decreases (Lee, Mayers \& Smith, 1997). The results of most of the empirical studies in the insurance sector support the finite risk paradigm (e.g., Cummins \& Sommer, 1996; Baranoff \& Sager, 2003; Shim, 2010).

\section{Data and methodology}

The non-life insurance sector accounted for 77 percent of the total insurance premium generated on the Serbian insurance market in 2019. It comprised twelve insurance companies, including six companies providing exclusively non-life insurance, and six composite insurers, providing life and non-life 
insurance. Units of observation in our analysis were companies that had continuous operations between 2006 and 2019. These are nine companies (five composite insurers and four exclusively non-life insurers), generating 126 observations for each variable. These companies accounted for 93.7 percent of the total non-life insurance premium in the third quarter of 2020 (National Bank of Serbia, 2020). Accordingly, our sample can be considered representative of the sector.

We performed a panel-data regression analysis based on the balance sheets and income statements gathered from the website of the National Bank of Serbia (www.nbs.rs). We used leverage (LEV), defined as the ratio of technical reserves to capital and expressed in percent, as our dependent variable. An insurer's probability of insolvency is determined by its capitalization relative to liabilities to policyholders. Being subject to strict regulation and control, insurance companies rarely take loans or issue bonds. Hence, the share of debt in an insurer's capital structure is low. To cover liabilities arising from insurance contracts, insurance companies form technical reserves by allocating and accumulating funds from the current technical premium. Dhaene et al. (2017) compare the balance sheets of insurance companies to that of industrial firms and point out two crucial differences. First, because of the inverted production cycle, policyholders finance the insurance company's activities through the upfront payment of premiums. Therefore, the clients of insurers are at the same time their financiers, i.e., the debtholders. Second, to meet their future claims, insurance companies must invest in highly marketable securities. This requirement is mandatory by the regulatory standards as well. Consequently, technical reserves are the primary driver of financial liabilities in insurance. This rationale justifies our choice of technical reserves to capital ratio as a proxy of the insurer's leverage.

Our choice of explanatory variables is based on related empirical studies. Age of insurer (AGE) captures the company's presence in the Serbian insurance market in years. As a proxy for insurer size, we used the natural logarithm of its annual written premium (SIZE). To measure the impact of diversification, we introduced the line-of-business Herfindahl-Hirschman index $(\mathrm{HHI})$. The index is calculated for each insurer based on the fraction of direct premium over its business lines. We captured the insurer's growth through the one-year percentage change in written premia (GROWTH).

The profitability is proxied by the combined ratio $(\mathrm{CR})$ : 
$C R=\frac{\text { Net Incurred Claims }+ \text { OpEx }}{\text { Net Earned Premium }}$.

Incurred claims include claims paid during the year, adjusted for the change in claim reserves. Earned premium refers to the written premium increased by unearned premium at the beginning of the year and reduced by unearned premium at the end of the year. All variables are included on a net basis (i.e., allowing for reinsurance). For non-life insurance companies, the combined ratio is a more direct measure of profitability than the return on assets used in most previous studies. On the other hand, only the total value of operating expenses is available for composite insurers. Therefore, the data were adapted for calculating the combined ratio, using the following approximation based on the assumption of a proportional share of the two operation types:

$$
\mathrm{OpEx}_{\text {Non-Life }}=\mathrm{OpEx}_{\text {Total }} \frac{\text { Written Premium }_{\text {Non-Life }}}{\text { Written Premium }_{\text {Total }}}
$$

As a proxy for insurer liquidity, we used the liquidity ratio (LIQUID), calculated as the ratio of current assets net of inventories (including unearned premiums and claim provisions), in percent. Finally, we measured insurer business risk as one-year percentage growth in incurred claims (RISK).

Our panel model has the following form:

$$
\begin{aligned}
& L E V_{i t}=\beta_{0}+\beta_{1 i}+\beta_{2} A G E_{i t}+\beta_{3} S_{I Z E_{i t}}+\beta_{4} H H I_{i t}+\beta_{5} G R O W T H_{i t}+ \\
& \beta_{6} C R_{i t}+\quad \beta_{7} \text { LIQUID }_{i t}+\beta_{8} \text { RISK }_{i t}+u_{i t}
\end{aligned}
$$

where $i=1, \ldots, 9$ denotes the cross-sectional dimension while $t=1, \ldots, 14$ denotes the time-series dimension, and $u_{i t}$ is the disturbance term. The coefficient $\beta_{1 i}$ captures all individual company characteristics that do not vary over time. Summary statistics for each of the variables are shown in Table 1.

To check for the potential multicollinearity of independent variables, we calculated the matrix of Pearson's correlation coefficients (Table 2). Since the 
correlation coefficients are not too high in absolute terms, we kept the full set of explanatory variables.

Table 1. Descriptive statistics of variables

\begin{tabular}{|l|r|r|r|r|r|}
\hline Variable & \multicolumn{1}{|c|}{ Mean } & \multicolumn{1}{c|}{ Median } & \multicolumn{1}{c|}{ Maximum } & \multicolumn{1}{c|}{ Minimum } & \multicolumn{1}{c|}{ St. dev. } \\
\hline LEV & 302.40 & 280.20 & 1840.12 & 9.61 & 256.78 \\
\hline AGE & 22.28 & 19.00 & 57.00 & 4.00 & 12.51 \\
\hline SIZE & 9.52 & 9.53 & 10.45 & 8.36 & 0.57 \\
\hline HHI & 0.390 & 0.330 & 0.829 & 0.150 & 0.202 \\
\hline GROWTH & 11.43 & 10.26 & 53.03 & -22.24 & 14.15 \\
\hline CR & 90.25 & 89.75 & 131.10 & 61.17 & 13.45 \\
\hline LIQUID & 141.46 & 114.87 & 565.65 & 40.41 & 95.36 \\
\hline RISK & 15.15 & 11.57 & 88.84 & -33.86 & 27.35 \\
\hline
\end{tabular}

Source: Authors' calculations based on NBS data.

Table 2. Pearson's correlation coefficients

\begin{tabular}{|c|c|c|c|c|c|c|c|c|}
\hline & LEV & AGE & SIZE & $\mathrm{HHI}$ & $\begin{array}{c}\text { GROWT } \\
\mathrm{H}\end{array}$ & $\mathrm{CR}$ & $\begin{array}{l}\text { LIQUI } \\
\text { D }\end{array}$ & RISK \\
\hline LEV & 1.000 & & & & & & & \\
\hline AGE & -0.220 & 1.000 & & & & & & \\
\hline SIZE & 0.277 & 0.499 & 1.000 & & & & & \\
\hline $\mathrm{HHI}$ & -0.108 & $0.34 \overline{1}$ & 0.639 & 1.000 & & & & \\
\hline GROWTH & 0.042 & $0.27 \overline{7}$ & $0.02 \overline{5}$ & 0.170 & 1.000 & & & \\
\hline CR & 0.027 & 0.005 & 0.476 & 0.348 & -0.096 & 1.000 & & \\
\hline LIQUID & 0.155 & 0.214 & 0.075 & $0.21 \overline{-}$ & -0.027 & -0.276 & 1.000 & \\
\hline RISK & 0.036 & $\begin{array}{r}- \\
0.275\end{array}$ & $0.11 \overline{-}$ & 0.122 & 0.503 & 0.184 & $\begin{array}{r}- \\
0.017\end{array}$ & 1.000 \\
\hline
\end{tabular}

Source: Authors' calculations.

\section{Results and discussion}

Based on available observations, three static panel data models were estimated: constant effects (pooled), fixed effects (FE) and random effects $(\mathrm{RE})$. We have determined the choice of the model specification by appropriate statistical tests. First, we reported the results of the Hausman test (Table 3). 34 
The difference between the estimated regression coefficients in the FE and the $R E$ model is statistically highly significant. This result is a strong indication that the appropriate choice is the model with fixed effects.

We tested for the presence of fixed effects using the $F$ test (Table 4). The null hypothesis that firm-level fixed effects are insignificant is overwhelmingly rejected (first row), implying that they should be preferred over the pooled regression model. The time-fixed effects are not significant (second row).

Table 3. The Hausman test results

\begin{tabular}{|c|r|r|r|}
\hline Test & \multicolumn{1}{|c|}{$\chi^{2}$ statistic } & $\begin{array}{c}\text { Degrees of } \\
\text { freedom }\end{array}$ & $p$-value \\
\hline Cross-section random & 362.78 & 7 & 0.0000 \\
\hline
\end{tabular}

Source: Authors' calculations.

Table 4. Testing for individual and time fixed effects

\begin{tabular}{|l|r|r|r|}
\hline \multicolumn{1}{|c|}{ Test } & \multicolumn{1}{|c|}{ F statistic } & $\begin{array}{c}\text { Degrees of } \\
\text { freedom }\end{array}$ & \multicolumn{1}{c|}{$p$-value } \\
\hline Individual fixed effects & 7.5414 & $(8,110)$ & 0.0000 \\
\hline Time fixed effects & 1.8957 & $(12,98)$ & 0.1439 \\
\hline
\end{tabular}

Source: Authors' calculations.

To check the ex-post validity of our FE model, we applied three tests, summarized in Table 5. First, the Pesaran cross-sectional dependence test (CD) examines whether the residuals are correlated across companies. The $p$ value of the test implies the absence of cross-sectional correlations. Second, the Wooldridge test shows that the absence of serial correlation in our FE model cannot be rejected at any reasonable significance level. Third, the BreuschPagan test indicates that the assumption of homoscedasticity should be rejected.

We controled for heteroskedasticity using the robust covariance matrix estimation (Kauermann \& Carrol, 2001). Table 6 shows the estimated FE model with heteroskedasticity-robust standard errors. Our proxies for the insurer's size, growth, profitability and liquidity exhibit a significant impact on company leverage. The regression is also jointly significant, having an $F$ statistic of around 6.9. 
Table 5. Testing for cross-sectional dependence, serial correlation and heteroskedasticity

\begin{tabular}{|l|r|r|}
\hline \multicolumn{1}{|c|}{ Test } & \multicolumn{1}{c|}{$\begin{array}{l}\text { Value of the } \\
\text { test statistic }\end{array}$} & \multicolumn{1}{c|}{$p$-value } \\
\hline Pesaran CD test & 0.4432 & 0.6576 \\
\hline $\begin{array}{l}\text { Wooldridge's test for serial } \\
\text { correlation }\end{array}$ & 1.7252 & 0.1916 \\
\hline Breusch-Pagan test & 322.57 & 0.0000 \\
\hline
\end{tabular}

Source: Authors' calculations.

Table 6. Regression results

\begin{tabular}{|l|c|}
\hline \multicolumn{1}{|c|}{ Variable } & Coefficient \\
\hline AGE & -0.0291 \\
& $(0.0873)$ \\
\hline SIZE & $3.6181^{* *}$ \\
& $(1.4661)$ \\
\hline GROWTH & $-2.3742^{* *}$ \\
& $(1.0345)$ \\
\hline HHI & 0.0759 \\
& $(0.0709)$ \\
\hline CR & $8.4480^{* *}$ \\
& $(0.4475)$ \\
\hline LIQUID & $-0.5599^{* * *}$ \\
& $(0.1133)$ \\
\hline RISK & -0.8333 \\
& $(0.5376)$ \\
\hline$R^{2}$ & 0.3047 \\
\hline Adjusted $R^{2}$ & 0.2099 \\
\hline F-statistic & $6.8853^{* * *}$ \\
\hline
\end{tabular}

Source: Authors' calculations.

Standard errors are reported in parentheses.

${ }^{*}-p$-value $<0.10 ;{ }^{* *}-p$-value $<0.05 ;{ }^{* *}-p$-value $<0.01$.

The estimated FE model indicates that the company's size and combined ratio positively affect the leverage, whereas the premium growth and liquidity are negatively associated with the leverage. On the other hand, the company's age, underwriting portfolio diversification and growth of incurred claims were not found to be statistically significant.

36

Industrija, Vol.49, No.1, 2021 
A positive relation between insurer size and leverage is consistent with the tradeoff theory. It confirms the view that relatively larger insurance companies can sustain more leverage since they require less capital to maintain their solvency. A similar result has been reported by Altuntas et al. (2015), Fier et al. (2013) and Cheng \& Weiss (2012). Additionally, for the Serbian non-life insurers, we can interpret this result simply by the fact that larger companies tend to disperse their operations to composite insurance. These companies have technical reserves dominated by the extensive mathematical reserve of life insurance, which does not exist in smaller companies with an exclusive focus on non-life insurance. At the same time, diversification into other business lines does not influence their leverage significantly.

A negative relation between growth and technical reserves to capital ratio also conforms to the tradeoff theory. This finding is in accord with Shim (2010). A more detailed analysis of the data reveals that the fast-growing Serbian insurers are mostly relatively new companies whose insurance premiums are still growing faster than technical provisions. As their capital base grows, the leverage decreases. However, the increase in insurer's liabilities towards policyholders follows the increase in business volume. The increase in volume, in turn, results in relatively larger technical reserves. If the premium grows too aggressively, the insurer's actuarial risk exposure may exceed available buffers. This mechanism is of the principal causes of insolvency.

The combined ratio represents an inverse metric of the profitability of non-life insurance operations. The greater the combined ratio, the less successful is this vital segment of the insurance company's activities. A higher combined ratio leads to an increase in the ratio of technical reserves to capital, everything else being unchanged. Thus, the relation between the profitability and leverage of non-life insurers in Serbia is negative, consistent with the pecking order theory. This negative relationship is intuitive since losses in the insurance business ultimately reduce insurers' capital and vice versa. The result is also consistent with many previous studies of determinants of insurer capital structure (i.e., Shim, 2010; de Haan \& Kakes, 2010; Kinde, 2013).

Finally, a significant negative interdependence between leverage and liquidity is compatible with the pecking order theory. Relatively lower predictability of insurance liabilities requires a higher capitalization of non-life over life insurers. The evidence from practice supports this result (Baranoff \& Sager, 2002). At the same time, non-life insurers hold more cash equivalents and other liquid assets due to the short-term nature of their liabilities. As our sample includes both composite and exclusively non-life insurers, the negative impact of liquidity on insurers' leverage could be expected. This result coincides with the earlier results of Ahmed et al. (2010), Najjar \& Petrov (2011) and Takele \& Beshir (2017). 


\section{Conclusion}

The primary role of capital in an insurance company is to buffer unexpected losses. Therefore, the amount of capital an insurance company holds relative to its liabilities to policyholders determines its insolvency probability. Application of the classical ideas of corporate finance-particularly the tradeoff and the pecking order theory-to insurers' financing choices helps to understand the forces that govern their solvency. Identifying factors affecting an insurer's leverage is thus essential to gain insight into the risk-return interplay mechanisms. Exploring this nexus is necessary both from a practical and regulatory perspective.

This paper investigated the influence of firm-level attributes on the capital structure of non-life insurance companies in Serbia from 2006 to 2019. Our results show that size, growth, profitability, and liquidity significantly influence the capital structure. Non-life insurers follow pecking order theory in terms of a negative impact of profitability and liquidity on leverage. On the other hand, a positive impact of size and a negative impact of growth on the insurer's leverage is in accord with the tradeoff theory. Results also indicate that insurer's age, underwriting portfolio diversification and growth of incurred claims do not influence leverage significantly.

This study is one of the first attempts to examine the applicability of the mainstream capital structure theories in the Serbian insurance market. From a practical point of view, our findings could be of interest to top managers of insurance companies operating in Serbia for the sake of finding optimal capital structure. Further, by explaining determinants of the capital structure of non-life insurers, our study gives valuable information to control and preserve their capital adequacy. Thus, the obtained results can be a useful input for designing a new framework for assessing the solvency of insurance companies.

Future research on this topic in Serbia would undoubtedly benefit from examining capital structure determinants for life insurance companies, as their business model is substantially different. Additionally, a more comprehensive study could include macroeconomic and other industry-wide variables as potential capital structure determinants. One of the major challenges to the study is that it focuses on a single insurance market over a period of fourteen years. More general conclusions could be drawn on an extended dataset that would include more countries and regions. 


\section{References}

Ahmed, N., Ahmed, Z., \& Ahmed, I. (2010). Determinants of Capital Structure: A Case of Life Insurance Sector of Pakistan. European Journal of Economics, Finance and Administrative Sciences, 6(24), 1450-1475. Retrieved from http://joc.hcc.edu.pk/faculty_publications/ejefas_24_01.pdf

Ahmed, R., \& Bhuyan, R. (2020). Capital structure and firm performance in Australian service sector firms: A panel data analysis. Journal of Risk and Financial Management, 13(9), 214.

Altuntas, M., Berry-Stölzle, T. R., \& Wende, S. (2015). Does one size fit all? Determinants of insurer capital structure around the globe. Journal of Banking and Finance, 61, 251-271, doi: 10.1016/j.jbankfin.2015.09.012

Antoniou, A., Guney, Y., \& Paudyal, K. (2002). The determinants of corporate capital structure: Evidence from European countries. Working paper. Retrieved from https://www.researchgate.net/publication/239504636_Determinants_of_Corporat e_Capital_Structure_Evidence_from_European_Countries

Baranoff, E. G., \& Sager, T. W. (2003). The relations among organizational and distribution forms and capital and asset risk structures in the life insurance industry. Journal of Risk and Insurance, 70(3), 375-400, doi: 10.1111/15396975.t01-1-00057

Cheng, J., \& Weiss, M. A. (2012). Capital structure in the property-liability insurance industry: tests of the tradeoff and pecking order theory. Journal of Insurance Issues, 35(1), 1-43. Retrieved from www.jstor.org/stable/41946324

Cummins, J. D., \& Nini, G. P. (2002). Optimal Capital Utilization by Financial Firms: Evidence from the Property-Liability Insurance Industry. Journal of Financial Services Research, 21(1-2), 15-53, doi: 10.1023/A:1014369617192

Cummins, J. D., \& Sommer, D. W. (1996). Capital and risk in property-liability insurance markets. Journal of Banking and Finance, 20(6), 1069-1092, doi: 10.1016/03784266(95)00044-5

De Haan, L., \& Kakes, J. (2010). Are non-risk based capital requirements for insurance companies binding? Journal of Banking and Finance, 34(7), 1618-1627, doi: 10.1016/j.jbankfin.2010.03.008

Dhaene, J., Van Hulle, C., Wuyts, G., Schoubben, F., \& Schoutens, W. (2017). Is the capital structure logic of corporate finance applicable to insurers? Review and analysis. Journal of Economic Surveys, 31(1), 169-189, doi: 10.1111/joes.12129

EIOPA. (2020). Financial Stability Report (December 2020). Luxembourg: Publications Office of the European Union.

Fier, S. G., McCullough, K. A., \& Carson, J. M. (2013). Internal capital markets and the partial adjustment of leverage. Journal of Banking and Finance, 37(3), 1029-1039, doi: 10.1016/j.jbankfin.2012.11.003

Frank, M., \& Goyal, V. (2005). Tradeoff and pecking order theories of debt. In: B. E. Eckbo (Ed.), Handbook of Empirical Corporate Finance, Vol. 2, Part 3. (pp. 135202). Amsterdam: Elsevier.

Guruswamy, D., \& Marew, A. (2016). Determinants of Capital Structure of Selected Insurance Companies in Ethiopia. Developing Country Studies, 6(10), 6-20. Retrieved from https://www.iiste.org/Journals/index.php/DCS/article/view/33353 
Harrington, S. E., \& Niehaus, G. (2002). Capital structure decisions in the insurance industry: stocks versus mutuals. Journal of Financial Services Research, 21(1), 145-163.

Harris, M., Raviv, A. (1990). Capital Structure and the Informational Role of Debt. Journal of Finance, 45(2), 321-349, doi: 10.2307/2328660

Hermanns, J. (2007). Optimale Kapitalstruktur und Market Timing: Empirische Analyse börsennotierter deutscher Unternehmen. Berlin: Springer-Verlag.

Kauermann, G., \& Carrol, R. J. (2001). A Note on the Efficiency of Sandwich Covariance Matrix Estimation. Journal of the American Statistical Association, 96(456), 13871396, doi: 10.1198/016214501753382309

Kinde, B. A. (2013). Impact of Firm Level Factors on Capital Structure: Evidence from Ethiopian Insurance Companies. Global Journal of Management and Business Research Finance, 13(4), 22-30. Retrieved from https://globaljournals.org/GJMBR_Volume13/5-Impact-of-Firm-Level-Factors.pdf https://journalofbusiness.org/index.php/GJMBR/article/view/979

Kraus, A., \& Litzenberger, R. H. (1973). A state-preference model of optimal financial leverage. Journal of Finance, 28, 911-922, doi:10.2307/2978343

Leaven, R. J. A., \& Perotti, E. C. (2010). Optimal Capital Structure for Insurance Companies. SSRN Electronic Journal, doi: 10.2139/ssrn.1730231

Lee, S.-J., Mayers, D., \& Smith Jr., C, (1997). Guaranty funds and risk-taking: Evidence from the insurance industry. Journal of Financial Economics, 44(1), 3-24, doi: 10.1016/S0304-405X(96)00007-4

Modigliani, F., \& Miller, M. H. (1958). The Cost of Capital, Corporate Finance, and the Theory of Investment. American Economic Review, 48(4), 261-297. Retrieved from https://www.jstor.org/stable/1809766

Myers, S. C. (1984). The Capital Structure Puzzle. Journal of Finance, 39(3), 575-92, Retrieved from https://onlinelibrary.wiley.com/doi/epdf/10.1111/j.15406261.1984.tb03646.x

Myers, S. C. (2001). Capital structure. Journal of Economic Perspectives, 15(2), 81-102, doi: 10.1257/jep.15.2.81

Myers, S. C. (2003). Financing of corporations. In: G. M. Constantinides, M. Harris \& R. M. (Eds.), Handbook of the Economics of Finance, Vol. 1, Part 1. (pp. 215-253). Amsterdam: Elsevier.

Myers, S. C., \& Majluf, N. S. (1984). Corporate Financing and Investment Decisions When Firms Have Information That Investors Do Not Have. Journal of Financial Economics, 13(2), 187-221, doi: 10.1016/0304-405X(84)90023-0

Najjar, N., \& Petrov, K. (2011). Capital Structure of Insurance Companies in Bahrain. International Journal of Business and Management, 6(11), 138-145, doi: $10.5539 / \mathrm{ijbm} . v 6 \mathrm{n} 11 \mathrm{p} 138$

National Bank of Serbia (2020). Insurance undertakings operations. Retrieved from https://nbs.rs/en/finansijske-institucije/osiguranje/poslovanje

Sherif, M., \& Elsayed, M. (2013). The impact of corporate characteristics on capital structure: evidence from the Egyptian insurance companies. Egyptian Business Administration Review, 1, 1-29, Retrieved from https://www.virtusinterpress.org /IMG/pdf/Mohamed_Sherif_Mahmoud_Elsayed_paper.pdf 
Shim, J. (2010). Capital-based regulation, portfolio risk and capital determination: Empirical evidence from the U.S. property-liability insurers. Journal of Banking and Finance, 34(10), 2450-2461, doi: 10.1016/j.jbankfin.2010.04.003

Takele, Y., \& Beshir, D. (2017). Firm-Specific Determinants of Insurance Companies' Capital Structure in Ethiopia. In: Heshmati, A. (Ed.), Studies on Economic Development and Growth in Selected African Countries (pp. 155-175), Singapore: Springer Nature.

Tornyeva, K. (2013). Determinants of capital structure of insurance companies in Ghana. Research Journal of Finance and Accounting, 4(13), 52-60. Retrieved from https://www.iiste.org/Journals/index.php/RJFA/article/view/7780/0

Öner Kaya, E. (2015). The effects of firm-specific factors on the profitability of non-life insurance companies in Turkey. International Journal of Financial Studies, 3(4), 510-529. 